\title{
THE ABSOLUTE COMPETENCE OF THE JURISDICTION OF THE ADMINISTRATIVE COURT IN A DISPUTE WHOSE OBJECT IS A FICTIVE-POSITIVE KTUN
}

\section{Francisca Romana Harjiyatni*}

\author{
Administrative Law Department, Faculty of Law, Universitas Janabadra \\ Jalan Timoho II/40, Kota Yogyakarta, D.I. Yogyakarta, 55165
}

\begin{abstract}
Based on the Law on Administrative Court, the Administrative Court has the competence to examine and decide upon a dispute whose object is a fictive-negative decision (KTUN). After the enactment of the Law No. 30 of 2014 on Government Administration, the Administrative Court has the competence to examine and decide a dispute whose object is a fictive positive KTUN. The provision of the positive decision in the Law No. 30 of 2014 provides fairer legal protection to both procedural justice and substantive justice. However, the force power of the court to execute decision remains low. Consequently, a fair legal protection to the dispute of positive KTUN per the Law No. 30 of 2014 is not optimal.
\end{abstract}

Keywords: absolute competence, administrative court, positive decision.

\section{Intisari}

Berdasarkan UU PTUN, PTUN mempunyai kewenangan untuk memeriksa dan memutus sengketa yang obyeknya KTUN fiktif negatif. Setelah berlakunya UU No. 30 Tahun 2014 tentang Administrasi Pemerintahan, PTUN mempunyai kewenangan memeriksa dan memutus sengketa yang obyeknya KTUN fiktif positif. Ketentuan KTUN fiktif positif dalam UU No. 30 Tahun 2014 lebih memberikan perlindungan hukum yang adil baik keadilan prosedural maupun keadilan substansial, namun dalam hal daya paksa pelaksanaan masih rendah maka perlindungan hukum yang adil dalam sengketa KTUN fiktif positif berdasarkan UU No. 30 Tahun 2014 menjadi tidak optimal.

Kata Kunci: kewenangan absolut, PTUN, keputusan fiktif positif.

\section{Pokok Muatan}

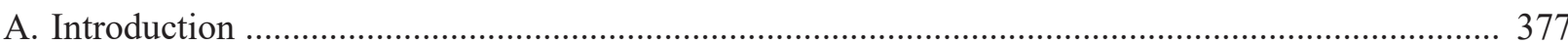

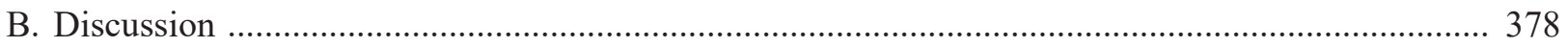

1. PTUN Absolute Competence in a Dispute Whose Object is a Fictive-Positive KTUN ............. 378

2. The Weakness of Fictive-Positive KTUN Regulations .............................................................. 384

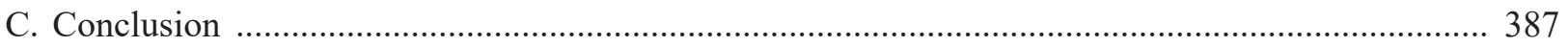




\section{A. Introduction}

The existence of the Jurisdiction of State Administrative Court (hereinafter referred as PTUN - Peradilan Tata Usaha Negara) is inseparable from the rule of law concept. In a State of law, there is no one who is immune to the law. The justice seeker can sue the government official who violates the rules of the administrative law and harms the people to the PTUN. In a State of law, it is the law that occupies the highest place. Frans Magnis Suseno argues that:

\begin{abstract}
A State of law is based on a desire that the State's authority shall be administered based on good and fair law. The law becomes the basis of all State's actions, and the law itself must be good and fair; because it is in accordance with what the people expect from the law and it must be fair because the basic purpose of all laws is justice. ${ }^{1}$
\end{abstract}

The government official in administering his duties and authorities shall also base on the applicable laws. In case the government official does an action that violates the law, in the State of law, this cannot be overlooked but submitted to the judicial institution namely the Administrative Court or PTUN. The existence of PTUN is a characteristic of State of law. PTUN is a place for the people who are harmed by the government to fight for their rights that have been violated. The presence of PTUN shows that there is no one who is immune to the law; anyone shall abide the law and the official who violates the law and harms the people can be filed to the PTUN.

PTUN was formed in 1986. After its establishment until now, there has been a dynamic improvement in PTUN regulations, particularly the last improvement related to its absolute competence. According to the Law No. 5 of 1986 on the Jurisdiction of State Administration jo Law No. 9 of 2004 on the First Amendment of the Law No. 5 of 1986 , the absolute competence or authority of
PTUN is examining, deciding and settling disputes regarding state administration (Tata Usaha Negara - TUN). Article 1 (10) of the Law No. 51 of 2009 stipulates that:

State administrative dispute is a dispute arising in the field of state administration between the people community or private legal entity and the government administrative official, either in the central or regional, as an impact of the issuance of a state administrative decision, including the dispute regarding employment based on the prevailing laws and regulations. ${ }^{2}$

Such definition shows that the absolute competence of PTUN is very narrow since it is limited to: (1) The dispute that arises in the field of state administration between the people community or private legal entity and TUN Official or Institution. This shows that the TUN official agency that administers the executive function is the one who can be filed to PTUN; (2) The dispute that arises because of the issuance of the state administrative decision (Keputusan Tata Usaha Negara-KTUN); and (3) The dispute in the field of employment. Besides such competence, PTUN also settles the dispute whose object is KTUN that has fictive-negative characteristic. It is regulated under Article 3 of the Law No. 5 of 1986 that stipulates: (1) If a TUN Official or Agency does not issue a decision while it is his obligation, thus it is equated with KTUN; (2) If a TUN Official or Agency does not issue a requested decision, while the period as has been stipulated by the laws and regulations has been elapsed, such TUN official or agency is considered to have refused to issue such decision; and (3) In case such relevant laws and regulations regulation does not stipulate the period as has been stipulated under paragraph (2), after the period of four months since the receipt of the request, the relevant TUN Official or Agency is considered to have issued a rejection decision. ${ }^{3}$

In such situation, although there is no written

Frans Magnis Suseno, 1988, Etika Politik, Gramedia, Jakarta, p. 295.

Article 1 (10) of the Law No. 51 of 2009 concerning second revision of the Law No. 5 of 1986 concerning PTUN (State Gazette of the Republic of Indonesia Year 2009 Number 160, Supplement of State Gazette of the Republic of Indonesia Number 5079).

Artile 3 of the Law No. 5 of 1986 concerning PTUN (State Gazette of the Republic of Indonesia Year 1986 Number 77, Supplement of State Gazette of the Republic of Indonesia Number 4380). 
KTUN that has been issued, the silence of the TUN Official or Agency to such people's request is considered as a negative KTUN in the form of rejection to such request, and its settlement can be asked through PTUN. After the Law No. 30 of 2014 on Government Administration entries into force, the provision regarding fictive-negative KTUN in the Law on PTUN is changed to be fictive-positive KTUN. This is regulated in Article 53 of the Law on Government Administration that stipulates as follows: ${ }^{4}$

(1) The time limit of the obligation to establish and/or perform the Decision and/or Action is in accordance with the provisions of the laws and regulations;

(2) If the provisions of the laws and regulations does not determine the time limit of the obligation as has been referred in paragraph (1), thus the Government Agency and/or Official shall decide and/or perform the Decision and/or Action within 10 (ten) working days after the request has been accepted completely by the Government Agency and/or Official;

(3) If within the time limit as referred in paragraph (2) the Government Agency and/or Official does not decide and/or perform the Decision and/or Action, thus such request is considered to have been granted legally;

(4) The Applicant submits the request to the Court to obtain the judgment of request approval as referred in paragraph (3);

(5) The Court shall decide the request as referred in paragraph (4) within 21 (twenty-one) working days at the longest after the request is submitted; and

(6) The Government Agency and/or Official shall decide the Decision to execute the Court judgment as has been referred in paragraph (5) within (five) working days at the longest after the Court judgment is ruled.

According to such provision, if the government official within ten days does not process or ignores the request that has been submitted by the community, there is an assumption that the request submitted is considered granted. Based on the explanation described on the research background, it is formulated the problems as follows: (1) How is the regulation of absolute competence of PTUN in a dispute whose object is a fictive-positive KTUN?; and (2) What are the deficiencies of the fictivepositive KTUN regulations?

\section{B. Discussion}

1. PTUN Absolute Competence in A Dispute Whose Object is a Fictive-Positive KTUN

The English word of competency or competence is coming from Latin word competentia, which in Bahasa Indonesia is called as kompetensi, means authority. Kamus Besar Bahasa Indonesia, what is meant by competence is an "authority (power) to decide and or determine something. ${ }^{5}$ In the judiciary world, particularly PTUN, there are two kinds of competence or authority owned by PTUN, namely; the relative and the absolute competence. According to Marbun:

The relative competence is the court's jurisdiction to adjudicate a case in accordance with its jurisdiction region, whereas the absolute competence is the court's jurisdiction in accordance with the object or the subject matter of the dispute. ${ }^{6}$

Concerning the absolute competence, Darwan Prinst argues as follows:

The absolute competence is related to the authority of the judiciary agency to assess a case, whether it is the jurisdiction of the general court, military court, religious court or state administrative court.?

\footnotetext{
Article 53 of Law No. 30 of 2014 concerning Government Administration (State Gazette of the Republic of Indonesia Year 2014 Number 292 , Supplement of State Gazette of the Republic of Indonesia Number 5601).

Departemen Pendidikan Nasional, 2002, Kamus Besar Bahasa Indonesia, Edisi Ketiga, Balai Pustaka, Jakarta, p. 584.

Marbun, S.F., 2011, Peradilan Administrasi Negara dan Upaya Administratif di Indonesia, Cetakan Ketiga (Revisi), FH UII Press, Yogyakarta, p. 239

Darwan Prinst, 1995, Strategi Menangani Perkara Tata Usaha Negara, Citra Aditya Bakti, Bandung, p. 17.
} 
The absolute competence of an administrative court (or known as PTUN in Indonesia) is varied in every country. According to Sabien Lust, the absolute competence of Belgian PTUN is:

The most important administrative jurisdiction is the Council of State (Raad van State-Conseil d'Etat), especially its administration section. This jurisdiction did not (only) get specific jurisdictional power, but got general jurisdiction to annul all acts of administration, both individual and regulatory, without regard to the legislation on which they are based. ${ }^{8}$

Essentially, the administrative court in Belgium is limited to the jurisdiction to annul all government decisions whether it is an individual or regulatory. To obtain the reimbursement of all losses suffered, the community as the claimant can file a lawsuit to the ordinary court (such as district court in Indonesia). State that embraces the AngloSaxon legal system does not recognize the standalone administrative jurisdiction. It only recognizes one judicial agency to adjudicate all kinds of dispute including the dispute regarding the legitimacy of the actions of the government officials. The suit against the legitimacy of the actions performed by the government officials is known as Judicial Review. Regarding the judicial review, Peter Cane said that:

In a general sense, judicial review refers to the judicial control of public decision making in accordance with rules and principles of administrative law. The mechanism for seeking judicial review in this sense is by making a claim for judicial review. The claim for judicial review is defined as a claim to review the lawfulness of (i)an enactment; or (ii) a decision, action or failure to act with the exercise of a public function. Most judicial review claims are made by judicial review procedure, and these claims are made to the Administrative Court, which is part of the High Court. ${ }^{9}$
It can be interpreted that the judicial review is pointing out about the judicial supervision to the public decision making in accordance with the regulations and principles of the State Administrative Laws. The claim or the application of judicial review can be interpreted as an application to review the lawfulness of (i) a law or (ii) a decision, action, or failure to perform a public function. Most of the judicial review claims are done by judicial review procedure and made to the Administrative Court which is a part of the High Court. It can be concluded that the claim of the decision or action of the government official in a State which embraces the Anglo-Saxon legal system is a part of the judicial review. According to Alex Carroll, "judicial review is the legal process through which an individual may challenge the legality of the way in which any of these powers have been used." 10 According to Chris Taylor, "Judicial review is a mechanism to ensure the accountability of executive power within the constitution. As such, it allows the courts (under certain circumstances) to rule on the legality of how executive powers are exercised." 11

In a State which holds the European Continental legal system, the claim against an action or decision of the government official becomes the jurisdiction of a special agency, namely administrative court. In Indonesia, PTUN is an authorized agency to examine the legitimacy of the executive in performing its duties. According to the Law on PTUN, the jurisdiction of PTUN is limited in settling TUN disputes whose object is only written KTUN, and TUN disputes whose object is fictivenegative KTUN. Negative KTUN is obtained when an authorized official act passively by not issuing requested KTUN. It is regulated under Article 3 of the Law No. 5 of 1986 which stipulates: ${ }^{12}$

(1) If a TUN Official or Agency does not issue a decision while it is his

\footnotetext{
Sabien Lust, "Administrative Law in Belgium," in Rene Seerden, 2002, Administrative Law of the European Union, its member States and the United States, Intersentia, Antwerpen, p. 45.

Peter Cane, 2004, Administrative Law Fourth Edition, Oxford University Press, New York, pp. 28-29.

Alex Carroll, 2007, Constitutional and Administrative Law Fourth Edition, Pearson Education Limited, Essex, p. 307.

Chris Taylor, 2008, Constitutional and Administrative Law, Pearson Education Limited, Essex, p. 111.

Artile 3 of the Law No. 5 of 1986 concerning PTUN (State Gazette of the Republic of Indonesia Year 1986 Number 77, Supplement of State Gazette of the Republic of Indonesia Number 4380).
} 
obligation, thus it is equated with KTUN;

(2) If a TUN Official or Agency does not issue a requested decision, while the period as has been stipulated in the laws and regulations has been elapsed, such TUN official or agency is considered to have refused to issue such decision; and

(3) In case such relevant laws and regulations regulation does not stipulate the period as has been stipulated under paragraph (2), after the period of four months since the receipt of the request, the relevant TUN Official or Agency is considered to have issued a rejection decision.

According to such Article 3 of Law No. 5 of 1986, the criteria of negative KTUN are as follows: (1) There is a request from the community to the authorized official to issue a decision; (2) The authorized TUN Official or Agency is not issuing such decision; and (3) The time limit to issue the decision stipulated under the laws has passed. If the laws regulate the time-period, thus such timeperiod shall prevail. If the laws do not regulate any time-period, thus four months after the acceptance of the request is used as the time limit. By ignoring the request from the community, the Government Official has harmed the community who submit the request. Therefore, there is an assumption that there is a rejecting decision to such request. This is also applicable in Belgium's legal system. Sabien Lust said:

The competence of the Council to annul is not limited to explicit of administration. Under certain conditions, an implicit decision can be challenged as well. These conditions are specified in Article 14 (3) of the Coordinated Acts concerning the Council of State: if an administrative authority obliged to decide, and it refrains from doing this, a citizen can order it to decide. If the authority did not decide within four months from this order, its silence is considered to be an adverse decision, which can be challenged before the Council of State. This rule only applies when no action has attached other consequences the silence of the administration. ${ }^{13}$

Further Sabien Lust said:

Some acts provide for instance that the silence of the administration must be considered as a positive or negative decision under conditions other than Article 14 (3) of the Coordinated Acts concerning the Council of State. These specific regulations prevail over the general rule of Article 14 (3). ${ }^{14}$

In Belgium, by ignoring the request submitted by the community, within four months, the action of the government official who neglects such community's request can be filed to PTUN with an assumption that there is a rejecting decision. This is not much different to PTUN in Indonesia, within four months the government official neglects the request of the community, there is a presumption that there is a rejecting decision. After the enactment of the Law on Government Administration, there is a change in the provisions regarding fictive-negative KTUN.

In the Law on Government Administration, it is regulated otherwise. If the government official neglects the request submitted by the community, thus there is an assumption that there is a KTUN that grants the request of the community. Such KTUN is called as fictive-positive. It is regulated in Article 53 of the Law on Government Administration which stipulates as follows: ${ }^{15}$

(1) The time limit of the obligation to establish and/or perform the Decision and/or Action is in accordance with the provisions of the laws and regulations;

(2) If the provisions of the laws and regulations does not determine the time limit of the obligation as has been referred in paragraph (1), thus the Government Agency and/or

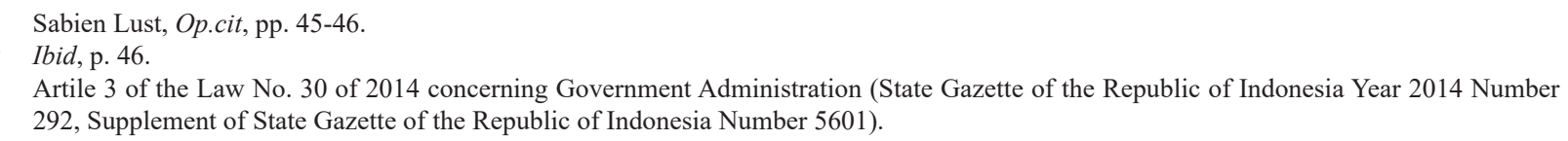


Official shall decide and/or perform the Decision and/or Action within 10 (ten) working days after the request has been accepted completely by the Government Agency and/or Official;

(3) If within the time limit as referred in paragraph (2) the Government Agency and/or Official does not decide and/or perform the Decision and/or Action, thus such request is considered to have been granted legally;

(4) The Applicant submits the request to the Court to obtain the judgment of request approval as referred in paragraph (3);

(5) The Court shall decide the request as referred in paragraph (4) within 21 (twenty-one) working days at the longest after the request is submitted;

(6) The Government Agency and/or Official shall decide the Decision to execute the Court judgment as has been referred in paragraph (5) within (five) working days at the longest after the Court judgment is ruled.

According to such provisions, if a government official within ten days does not process or chooses to neglect the request submitted by the community, thus it can be assumed that the request submitted by the community is granted. In this regard, the community can file a request to PTUN to receive a judgment in the form of the declaration of request acceptance. For such request, PTUN shall give its judgment within 21 days at the longest after the submission of the request. Such provisions certainly give more protection to the community since there is a certainty that the request is accepted compared to the provisions stipulated in the Law on PTUN.

A fair legal protection by the court can be achieved if from the examination process until the judgment and its implementation, it can give the feeling of justice either procedural or substantive. Regarding the procedural justice, Praveena SukhrajEly maintains that "Where processes of law are not adhered to by persons requesting decisions and decision makers, a fair outcome with regard to justice is unlikely". ${ }^{16}$ In the case that the decision maker does not respond the objection raised by the community and merely neglects the request submitted by the community, that is an injustice action. There shall be a certain procedure for the decision maker who neglects the community's request.

There shall be a fair legal protection for the community who long for obtaining a decision from the government official. A fair legal protection covers procedural and substantive justice. Procedural justice is related to a fair procedure for the community who apply to the government official to obtain a decision for themselves. Joseph Sanders and V. Lee Hamilton argue "If we come to believe the procedure is fair this judgment anchors our overall assessment to such an extent that subsequent outcome information has relatively little effect". ${ }^{17}$ A fair procedure will bring relatively small effect to the final result, meaning that the judgment will have a small chance of having unfair contents. A fair procedure for settling dispute whose object is a fictive-positive decision will produce fair judgment contents as well. In other words, it can be concluded that the procedural justice obtained from a fair procedural regulation will affect the result as well that is a fair judgment (or its substantive judgment is reached).

The Regulation of Fictive-Positive Decision by the Law No. 30 of 2014 provides fairer procedure than the regulation of Fictive-Negative regulated in the Law on PTUN since the Law No. 30 of 2014 provides a clear settlement process and a reasonably fast time limit. According to Tom R. Tyler:

The concepts of procedural justice have developed from research showing that the manner in which disputes are handled by the courts has a significant influence upon people's evaluations of their experiences in the court system. ${ }^{18}$ 
The experience of the people towards the process of dispute settlement performed by the court gives an idea that the procedural justice such dispute settlement through the court influences the justice obtained in the result of such process. The procedural justice is contained in a fair procedure in settling a dispute, and such procedure is applied in the practice of dispute settlement. The dispute settlement procedure whose object is fictive-positive KTUN in the Law on Government Administration is as follows: First, The obligation of the authorized government official to decide and/ or perform a Decision and/or Action in accordance with the provisions of the laws and regulations. Every government official is not allowed to neglect every application from the community who applies for the issuance of a decision and/or performance of a Decision and/or Action. Such Obligation Abandonment raises a right for the community to submit the application to the Administrative Court for such obligation abandonment.

Second, There is a time limit for the obligation to decide and/or perform a Decision and/or Action. Such time limit covers two things, namely: a) in accordance with the provisions of the laws and regulations; and b) within 10 (ten) working days at the longest after the request is accepted if the regulations do not regulate the time-period for the obligation to decide and/or perform a Decision and/or Action. By regulating such time limit for the government official to decide and/or perform a Decision and/or Action, it shows that there is a procedure that has a definite and firm deadline. Such procedure provides a high legal certainty to the time limit of the decision and/or action making by the government official. This procedure certainly provides fairer legal protection to the community who need the issuance of a decision or performance of an action for themselves.

Third, In case the Government Agency and/or Official does not decide and/or perform a Decision and/or Action in accordance with the time limit that has been stipulated, such request is considered granted legally. This stipulation provides more value to the feeling of justice compared to the fictive-negative decision. Forth, The community is given the right to file a request to the Administrative Court for the abandonment of the obligation of the government official to make a decision and/or perform actions requested by the community. For this request of the community, the Law on Government Administration regulates the procedure regarding the time limit for the Administrative Court in examining and deciding such request. The court shall decide the request within 21 (twenty-one) working days at the longest after the submission of the request. This stipulation provides clear procedure regarding the process of examining and deciding such request.

The time limit of the Administrative Court in examining and deciding such request is clear and fast. This is certainly a procedure that provides a fair legal protection for the community. The community does not have to wait for a long time to get a certainty regarding their request. Fifth, The Government Agency and/or Official has an obligation to execute the Court's judgment within 5 (five) working days at the longest after the Court's judgment is established. The Law on Government Administration provides a reasonably fast time limit for the government official and/or agency to issue his decision that is 5 (five) days after the Court's judgment is established. It is a procedure that provides enough legal protection to the community since they will obtain the decision as expected as soon as possible.

If the stipulation regarding such procedure is well applied by the Administrative Court in examining and deciding the community's request, the community will obtain a fair legal protection from its procedural justice aspect. In addition to the procedural justice aspect, a fair legal protection is also assessed by the Court from its substantive justice aspect. According to Wojciech Sadurski, "It is often maintained that substantive justice is justice of outcome while procedural justice is the justice of 
process which brings about this outcome" 19

Procedural justice refers to the justice in a process until it is resulted in a result, whereas the justice contained in a result obtained from a process is a substantive justice. The process or the procedure of TUN dispute settlement until getting a judgment that has legal binding force is the procedural justice. However, the fair result obtained from the examination process of TUN dispute in the form of PTUN judgment that has legal binding force which gives justice to the parties is the substantive judgment.

The existence of the provision that stipulates that in case the community's request does not receive any response from the government official thus there is an assumption that there is an approving decision for such request, from the substantive aspect is providing more legal certainty and justice. It gives legal certainty because with the action of government official who is silent towards the community's request, it means that the government official does not provide legal certainty to the community for their request, but through the provisions of the Law on Government Administration, the community is given a legal certainty through the assumption that there has been a decision in the form of acceptance of the decision (by granting the request of the community).

It is providing justice since there is an assumption of acceptance in the government official's decision. This is different with the Law on PTUN where there is an assumption of rejection in the government official's decision over the request of the community. The change of a rejection assumption per the Law on PTUN to become an acceptance Government Administration provides more justice from its substantive aspect. The stipulation regarding this fictive-positive decision can also become a motivation for the government officials in performing their duties and authorities so that they can become more cautious in the decision- making and acting, and able to give a right decision or deed to the community.

According to the matters that have been elaborated in the above paragraphs, they show that the regulation regarding a dispute whose object is a positive KTUN provides more legal protection to the justice seeker because they obtain the legal certainty regarding their request, that is their request is granted. The stipulation of this fictive-positive KTUN provides more legal protection to the justice seeker rather than the stipulation of fictive-negative KTUN. In relation with such fictive-positive KTUN, it has been issued the Supreme Court Regulation No. 5 of 2015 on the Procedure Guidelines for Obtaining a Decision on the Acceptance of the Request to Obtain a Decision and/or Action from the Government Agency or Officials. According to such Supreme Court Regulation No. 5 of 2015, regarding the fictive-positive KTUN, the Court can decide: ${ }^{20}$

1) 'Declaring that the applicant's request cannot be accepted," in case the request does not fulfill the formal requirements, the court does not have the jurisdiction, or the applicant does not have the legal standing.

2) - "Granting the applicant's request".

- "Obliging the government agency and /or officials to issue a decision and/or perform an action," in accordance with the applicant's request.

3) "Declaring that the applicant's request is rejected," in case that the reason for the request is groundless under the law.

4) "Declaring that the request is void," in case the applicant does not appear at the hearing two times in a row on the first and second trial without any valid reason or the applicant is not genuine.

Concerning the stipulation of the fictivepositive decision, the Supreme Court Regulation No. 5 of 2015 is issued as a guideline in the dispute 
settlement whose object is a Fictive-Positive Decision when the new version of the Law on PTUN has not been adjusted with the Law of Government Administration. Such regulation is, in fact, a guideline for the PTUN Judges in settling the dispute whose object is a Fictive-Positive Decision. For the community, there should be a guide that becomes a foundation for the people in settling the dispute whose object is a fictive-positive decision where its material content is set forth in the regulations in the form of the Law to harmonize the regulations between the Law of Government Administration and the Law on PTUN, so the regulation merely with the Supreme Court Regulation is not enough.

\section{The Weakness of Fictive-Positive KTUN Regulations}

The weakness of the regulations of fictivepositive KTUN is that there is no alteration made in the Law on PTUN to conform with the Law on Government Administration, so there are two provisions apply, namely the provisions of the fictivenegative KTUN in accordance with the Law on PTUN and the fictive-positive KTUN in accordance with the Law on Government Administration. In this regard, it is possible to file a claim whose object is a negative KTUN because the Law on PTUN is still applicable and has not been changed. It is possible to happen when the community is not aware of the provisions regarding the fictive-positive KTUN in the Law on Government Administration, and the time-period has elapsed, so there is a chance to file a claim based on the provisions of fictive-negative KTUN.

Problems can also arise when the community has submitted a request to the PTUN in accordance with the provisions of fictive-positive KTUN in the Law on Government Administration, but it is not granted by the Administrative Court: whether they can resubmit the claim to the Administrative Court in accordance with the provisions of the fictive- negative KTUN in the Law on PTUN because the period to submit a claim has not elapsed based on such law. It is possible to be done, considering that both laws, namely the Law on PTUN and the Law on Government Administration are still applicable. The abovementioned problem raises a new question, whether such matter is considered as "nebis in idem" or not. According to Muhammad Yusuf Ibrahim: ${ }^{21}$

Nebis In Idem is a case with the same object, the same parties, and the same subject matter, that is decided by the Court and has the legal binding force, either granting or refusing, cannot be examined for the second time.

Another opinion regarding nebis in idem is the opinion from Asriadi Zainuddin who says:

The criteria for a case that can be considered as Nebis In Idem is: what is claimed has been claimed, there is a judgment that has legal binding force and has positive character, such as refusing the case, has the same object, the same subject, the same subject matter. ${ }^{22}$

Based on both opinions, there are four elements to say that a case is nebis in idem namely: 1) the same object; 2) the same parties; 3 ) the same subject matter; 4) has been decided and has legal binding force. In case a TUN dispute whose object is fictive-positive KTUN has been decided by the court and declared not accepted, then re-submitted based on the provisions of fictive-negative KTUN in the Law on PTUN, if it is analysed based on the elements above, then it is obtained a result as follows: (a) In such case, the object is not the same because the first dispute the object is the fictivepositive KTUN, whereas in the second dispute the object is the fictive-negative KTUN; (b) The parties on such dispute whose object is either fictivepositive KTUN or fictive-negative KTUN are the same; (c) The subject matter in such dispute whose object is either fictive-positive or fictive-negative KTUN is the same, that is a request from the community who do not receive any response from

\footnotetext{
21 Muhammad Yusuf Ibrahim, "Implementasi Asas Nebis In Idem Dalam Perkara Yang Telah Memiliki Kekuatan Hukum Tetap Yang Digugat Kembali Dengan Sengketa Obyek Yang Sama Tetapi Dengan Subyek Yang Berbeda”, Jurnal Ilmiah Fenomena, Vol. XII, No. 1, May 2014, p. 1157.

22 Asriadi Zainuddin, "Penanganan Perkara Yang Berkaitan Dengan Azas Ne Bis In Idem”, Jurnal Al-Mizan, Vol. 10, No.1, June 2014, p. 140.
} 
the authorized government officials; and (d) Have been decided and have legal binding force.

Such analysis shows that if a dispute whose object is a fictive-positive KTUN has been decided by the Court and declared cannot be accepted or rejected by the Court, thus being resubmitted under the provisions of the dispute whose object is fictivenegative KTUN, thus it is not included in the case of nebis in idem, because the first element, having the same object is not fulfilled. It is said that a case is nebis in idem if all the elements are fulfilled. In case there is an element which is unfulfilled; thus, it cannot be said as a nebis in idem case. There needs to be a regulation that is an implementation guideline to overcome the problem of the timeperiod regulated by two different regulations, and both are still applicable.

In case of the dispute whose object is a fictivepositive KTUN has been granted by the Judge; thus, the Judge will state in his ruling that "Obliging the government agency and/or officials to issue a decision and/or perform an action", in accordance with the applicant's request. If the execution of such decision cannot be forced and the government officials as the respondent are unwilling to agree to execute the decision voluntarily, thus the justice seeker will not obtain a fair legal protection, or in other words, the justice seeker will not achieve the justice but merely winning on paper. If that is the case, the legal protection given by the Law on Government Administration to the people as the justice seeker in a case whose object is fictivepositive KTUN has no meaning.

The procedure of the Administrative Court in examining and deciding a case whose object is a fictive-positive TUN Decision should be balanced with the provisions regarding the implementation of the judgment that has strong force power. If it is not balanced with a strong force power to implement the judgment, thus the procedure that is considered fairer in the Law on Government Administration has less sense of justice, which in the end, the legal protection for the people becomes less optimal. Since it was formed until today, PTUN has weaknesses, so it cannot perform its function excellently in giving protection to the people. Regarding such matter, Stewart Fenwick argues:

The Court has steadily declined in prominence and has not found a voice in post-reform Indonesia. In many respects, the jurisdiction is largely invisible and is notable for its comparatively light caseload, poor enforcement powers, and an apparent inability to generate significant jurisprudence. ${ }^{23}$

In its development, PTUN has declined in its prominence primarily related to the weak enforcement power (execution) of the PTUN judgment. It is an institution that is formed to protect the people, however, when the respondent is unwilling to execute the judgment voluntarily, there is no mechanism that can be used to force the officials to perform it, so that the community is merely winning on paper. In such case, PTUN is failed in performing its function in giving protection to the people as the justice seeker. Further, Steward Fenwick argues, "While the draft Law on Government Administration sets out new standards for administrative decision-making, it does not alter the framework for review mechanisms in any fundamental way". ${ }^{24}$

In the course of time, eventually, the draft of Law on Government Administration is set forth as a law through the Law No. 30 of 204 on Government Administration which has been elaborated in the previous sub-chapter which gives an extension to PTUN's absolute competence. Hence, it brings an implication to the change of PTUN procedural law to conform itself to the change that has been regulated in the Law on Government Administration. Such change does cover not only expansion of the court's absolute competence, but also the evolution of the general principle of good governance as the testing tool and should be followed with an increase in the

\footnotetext{
23 Stewart Fenwick, "Administrative Law and Judicial Review In Indonesia-The Search For Accountability", Tom Ginsburg and Albert H. Y. Chen, Administrative Law and Governance in Asia Comparative Perspectives, Routledge, Oxon, p. 329.

24 Ibid.
} 
force power of the judgment execution.

Until now, there is no new Law on PTUN to conform with the Law on Government Administration. The concept or draft of the new Law on PTUN has ever compiled but delayed in the subsequent discussion, so that it has not been set until now. Concerning the execution of the judgment, such concept or draft or bill stipulates in its Article 134 as follows: (1) The court clerk at the behest of the Head of the Court sends a copy of the court judgment which has legal binding force to the parties and the Minister; (2) The respondent shall carry out the court judgment that already has legal binding force; (3) The President performs the supervision of the court judgment as the supreme head of the government; (4) The supervision as referred in paragraph (3) can be delegated to the minister; (5) The minister referred in paragraph (4) shall report the execution of the judgment that already has legal binding force to the Head of Supreme Court of Republic Indonesia with a copy to the Head of the Court in the first instance; (6) The Head of the Court coordinates with the Minister for the execution of the judgment that already has legal binding force; and (7) The Head of the Court reports the result of the execution of the judgment that already has legal binding force to the Supreme Court at the end of each year.

Based on such provisions, it shows that the execution of the Administrative Court judgment is entirely delegated to the executive or the government as the respondent to execute it. The Administrative Court as the judicial institution is not authorized at all to force the execution of PTUN judgment to be carried out by the government officials as the respondent. It is because the execution of judgment is given with full authorization by the Law on Government Administration to the government/ executive to execute it. Under Article 7 (2) k and
1 of the Law on Government Administration, it is stipulated that the government officials have obligations as follows: (a) Performing the Decision and/or Action which is valid and the Decision that has been declared invalid or voided by the Court, relevant officials or Officer's Supervisor; and (b) Obeying the Court judgment that already has legal binding force.

Further in Article 72 (2) of the Law on Government Administration it is stipulated that,

The Agency and/or Government Official shall carry out the Decision and/or Action and/or valid Action and decision that has been declared invalid by the Court or such relevant officials or the relevant supervisor. ${ }^{25}$

Such provisions show that the government officials have an obligation to obey the court judgment. An obligation is a legal stipulation that must be done by the government officials in performing their duties and authorities. In case such duties are not performed, there will be a sanction imposed, in this case, the sanction has been regulated in the Law on Government Administration. According to Article 80 paragraph (2) of the Law on Government Administration, a violation towards the stipulation of such Article 72 paragraph (2) will be imposed with medium administrative sanction. ${ }^{26}$ Under Article 81 (2) of the Law on Government Administration, medium administrative sanction covers: (a) The payment of non-compliance penalty and/or compensation; (b) Temporary dismissal while retaining the position's rights; or (c) Temporary dismissal without retaining the position's rights. ${ }^{27}$

Such provision shows that for the officials who do not execute the PTUN judgment, they will be imposed with sanction, among others, the payment of the non-compliance penalty or known as dwangsom. However, the authority to implement

25 Artile 72 (2) of the Law No. 30 of 2014 concerning Government Administration (State Gazette of the Republic of Indonesia Year 2014 Number 292, Supplement of State Gazette of the Republic of Indonesia Number 5601).

26 Artile 80 (2) of the Law No. 30 of 2014 concerning Government Administration (State Gazette of the Republic of Indonesia Year 2014 Number 292, Supplement of State Gazette of the Republic of Indonesia Number 5601).

27 Artile 81 (2) of the Law No. 30 of 2014 concerning Government Administration (State Gazette of the Republic of Indonesia Year 2014 Number 292, Supplement of State Gazette of the Republic of Indonesia Number 5601). 
the dwangsom is given to the executive and not to PTUN. It is further stipulated in Article 82 of Government Administration as follows: ${ }^{28}$

(1) The imposition of sanction as referred in Article 81 is performed by:

a. the supervisor of the Official who makes the Decision;

b. the head of the district if the Decision is made by a district official;

c. the minister/ the head of the institution if the Decision is made by the official in his workplace; and

d. the president if the Decision is made by the Minister/the head of the institution.

(2) The imposition of sanction as referred in Article 81 is performed by:

a. the governor if the Decision is made by Bupati or mayor; and

b. the minister who administers internal governance affairs if the Decision is made by the governor.

Pursuant to the abovementioned elaboration, it shows that the Law on Government Administration wants the authority to execute the PTUN judgment is entirely handed to the executive. PTUN as the judicative institution does not have any authority in executing the PTUN judgment. This is something very ironic because in one hand the Law on Government Administration gives a vast absolute competence to PTUN, but on the other hand, PTUN does not have the authority to execute PTUN judgment. It seems that the initiator of the Law on Government Administration is rather strict in implementing the theory of the separation of power so that PTUN is placed as a supervisory body.

PTUN judgment merely becomes a recommendation, and the follow-up of such recommendation is entirely handed to the executive, not much different with other supervisory bodies. In this regard, PTUN has functioned as a supervisory body that is not different with other supervisory bodies. The function as a judicial institution is less visible in PTUN because the characteristic of judicial institution has a full authority to settle case tried by it until the judgment of the court can be executed.

\section{Conclusion}

Based on the abovementioned elaboration, it can be concluded that, First, the regulation regarding the absolute competence of PTUN in a dispute whose object is fictive-positive KTUN in the Law No. 30 of 2014 on the Government Administration provides more legal protection to the people as the justice seeker. Legal protection from both substantive or procedural justice. From the substantive aspect, it provides more protection to the justice seeker because by not processing a request from the community within ten days at the latest, it is assumed from the government officials that there is an approval decision to such community's request. From the procedural aspect, the people obtain more legal protection because of a shorter procedural process, that is the dispute settlement whose object is a positive-fictive decision will only require 21 days, and the judgment is first and final.

Second, the regulation of fictive-positive decision has weaknesses, namely: 1) The Law on PTUN has not been conformed with the Law on Government Administration particularly regarding the regulation of fictive-positive KTUN; 2) The regulation of fictive-positive KTUN has a weakness related to the soft force power of the judgment execution. One of the rulings of judgment of a dispute whose object is a fictive-positive decision is an order for the respondent (in this case, is the government officials) to issue an approval decision on the request of the community as the claimant. In case the respondent is not voluntarily willing to execute the judgment of PTUN, the claimant does not completely obtain a legal protection in his case. 
Based on the problems arise afterthe enactment of the Law on Government Administration, it is given suggestions as follows; that it is needed to make a new Law on PTUN in conformity with the Law on Government Administration whose content among others: regulating the fictive-positive
Administrative Court's judgment, the stipulation of fictive-positive KTUN that is supposed to be followed by the regulation regarding the judgment execution that has more force power, and the need of an intense socialization to the people regarding the stipulation of fictive-positive KTUN.

\section{REFERENCES}

\section{A. Books}

Cane, Peter, 2004, Administrative Law, Fourth Edition, Oxford University Press, New York.

Carroll, Alex, 2007, Constitutional and Administrative Law, Fourth Edition, Pearson Education Limited, Essex.

Departemen Pendidikan Nasional, 2002, Kamus Besar Bahasa Indonesia, Third Edition, Balai Pustaka, Jakarta.

Fenwick, Stewart, "Administrative Law And Judicial Review In Indonesia-The Search For Accountability", Tom Ginsburg and Albert $\mathrm{H}$. Y. Chen, Administrative Law and Governance in Asia Comparative perspectives, Routledge, Oxon.

Magnis Suseno, Frans, 1988, Etika Politik, Gramedia, Jakarta.

Marbun, S.F., 2011, Peradilan Administrasi Negara dan Upaya Administratif di Indonesia, Third Edition (Revision), FH UII Press, Yogyakarta.

Prinst, Darwan, 1995, Strategi Menangani Perkara Tata Usaha Negara, PT Citra Aditya Bakti, Bandung.

Sadurski, Wojciech, 1985, Giving Desert Its Due: Social Justice and Legal Theory, D. Reidel Publishing Company, Dordrecht

Sanders, Joseph, and V Lee Hamilton, 2001, Handbook of Justice Research in Law, Kluwer Academic Publishers, New York, Boston, Dordrecht, London, Moscow.

Seerden, Rene J.G.H., (Ed.), Administrative Law of the European Union, its Member States and the United States-A Comparative Analysis,
Second Edition, Intersentia Antwerpen, Oxford.

Taylor, Chris, 2008, Constitutional and Administrative Law, Pearson Education Limited, Essex.

\section{B. Journal Articles}

Tyler, Tom R., "Procedural Justice and the Courts", Court Review, the Journal of American Judges Association, Vol. 44, Issues 1/2, 2007-2008.

Yusuf Ibrahim, Muhammad "Implementasi Asas Nebis In Idem Dalam Perkara Yang Telah Memiliki Kekuatan Hukum Tetap Yang Digugat Kembali Dengan Sengketa Obyek Yang Sama Tetapi Dengan Subyek Yang Berbeda", Jurnal Ilmiah Fenomena, Vol. XII, No. 1, May 2014.

Zainuddin, Asriadi, "Penanganan Perkara Yang Berkaitan Dengan Azas Ne Bis In Idem", Jurnal Al-Mizan, Vol. 10, No. 1, June 2014.

\section{Internet}

Sukhraj-Ely, Praveena, "Procedural Justice: The Thread that Weaves the Fabric of Justice in Society", http://hsf.org.za/resource-centre/ focus/focus-55-november-2009-images-ofjustice/procedural-justice, last access on 21 November 2016.

\section{Regulations}

Law No. 5 of 1986 concerning PTUN (State Gazette of the Republic of Indonesia Year 1986 Number 77, Supplement of State Gazette of 
the Republic of Indonesia Number 4380).

Law No. 51 of 2009 concerning second revision of the Law No. 5 of 1986 concerning PTUN (State Gazette of the Republic of Indonesia Year 2009 Number 160, Supplement of State Gazette of the Republic of Indonesia Number 5079).
Law No. 30 of 2014 concerning Government Administration (State Gazette of the Republic of Indonesia Year 2014 Number 292, Supplement of State Gazette of the Republic of Indonesia Number 5601).

Supreme Court Regulation No. 5 of 2015. 